\title{
T-CENTER ST. MARX ${ }^{\text {WIENIVIENNA }}$
}




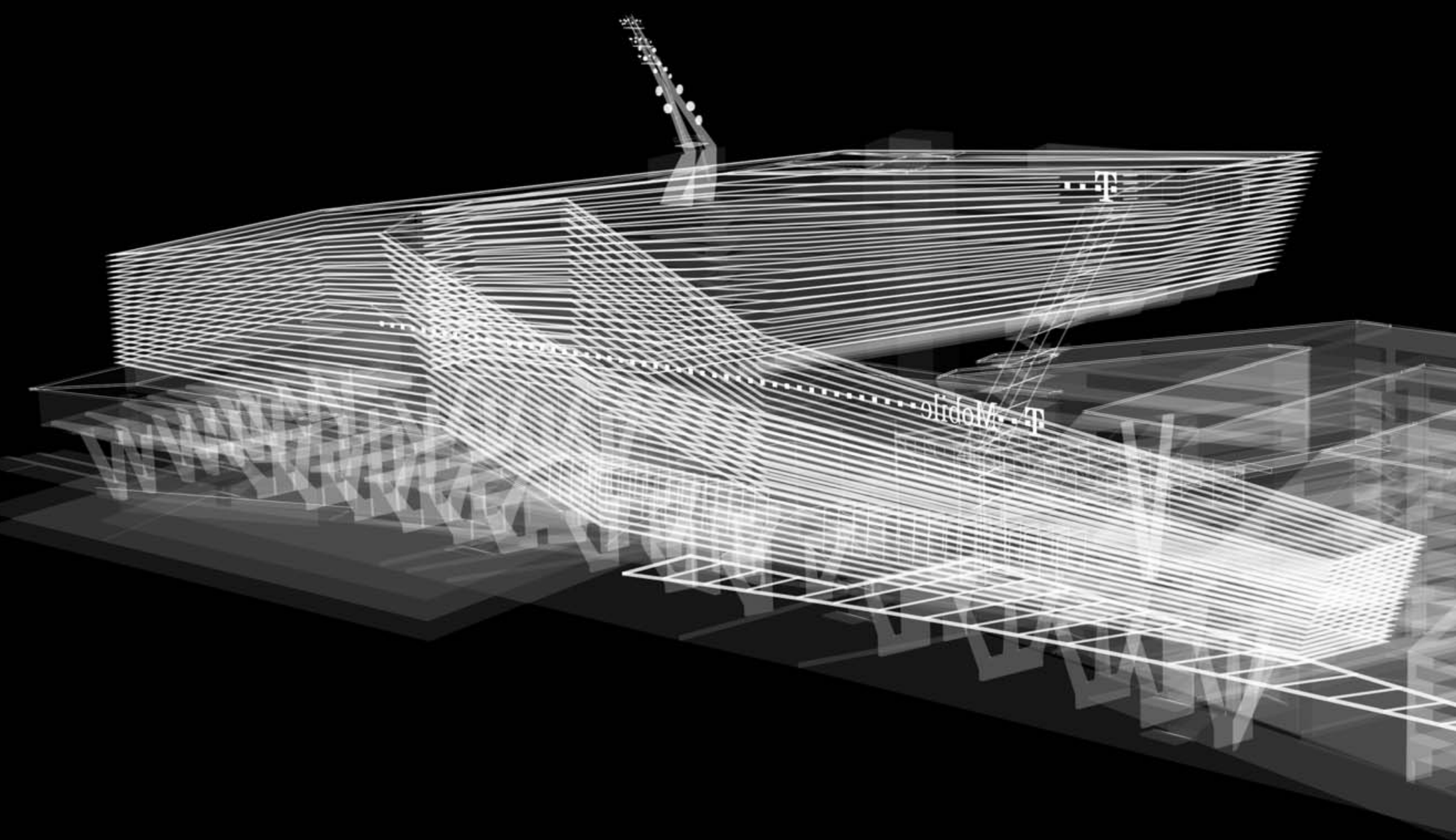

BIRKHÄUSER - Verlag für Architektur I Publishers for Architecture Basel · Berlin · Boston 
DOMENIG I EISENKÖCK I PEYKER LIESBETH WAECHTER-BÖHM

\section{T-CENTER ST. MARX \\ WIEN I VIENNA}


Herausgeber I Editor

Konzept und Organisation I Concept und Organization

Grafische Gestaltung | Graphic Design

Übersetzungen | Translations

Fotos Architektur I Photos Architecture Fotos Skizzen und Modelle I Photos Sketches and Models Fotos Interview I Photos Interview Luftaufnahmen | Aerial Photos Rendering

Druck und Bindung I Printing and Binding mm Liegenschaftsbesitz $\mathrm{GmbH}$

Dipl.Ing. Thomas Jakoubek: Geschäftsführer I CEO

Donau-City-Straße 1, A-1220 Wien

Tel.: 0043 (0) 1 - 2050112

Architektur Consult ZT GmbH

o. Prof. Arch.Dipl.Ing. Günther Domenig

Arch.Dipl.Ing. Hermann Eisenköck

Arch.Dipl.Ing. Herfried Peyker

Körblergasse 100, $8010 \mathrm{Graz}$, Austria

Tel.: 0043 (0) 316 - 323100

www.archconsult.com

Liesbeth Waechter-Böhm

Arch.Dipl.Ing. Hermann Eisenköck

Dipl.Ing. Thomas Jakoubek

Ing. Helmut Daschütz

Arch.DDipl.Ing. Christian Halm

die ORGANISATION, Graz

www.die-organisation.at

Mirela Hoiss, Graz

Paul Ott, Graz

Franz Ebner, Wien I Paul Ott, Graz

Günther Linshalm, Wien

Architektur Consult ZT GmbH, Graz

Zoom VP, Wien

Medienfabrik, Graz

A CIP catalogue record for this book is available from the Library of Congress, Washington D.C., USA

Bibliographic information published by Die Deutsche Bibliothek. Die Deutsche Bibliothek lists this publication in the Deutsche Nationalbibliografie; detailed bibliographic data is available in the Internet at http://dnb.ddb.de.

This work is subject to copyright. All rights are reserved, whether the whole or part of the material is concerned, specifically the rights of translation, reprinting, re-use of illustrations, recitation, broadcasting, reproduction on microfilms or in other ways, and storage in data banks. For any kind of use, permission of the copyright owner must be obtained.

(C) 2005 Birkhäuser - Publishers for Architecture

P.O.Box 133, CH-4010 Basel, Switzerland, www.birkhauser.ch

Part of Springer Science+Business Media

Printed on acid-free paper

Produced from chlorine-free pulp. TCF $\infty$

Printed in Austria

ISBN-13: 978-3-7643-7246-0

ISBN-10: 3-7643-7246-X

987654321 


\section{INHALT I CONTENTS}

DIE ENTSTEHUNG DES T-CENTER ST. MARX I THE GENESIS OF T-CENTER ST. MARX 06

DER WEG BIS ZUR ÜBERGABE I FROM DEVELOPMENT TO OPENING 08

EIN SAURIER HEBT AB I A DINOSAUR LIFTS OFF 12

PLANUNG I PLANNING 20

INTERVIEW I INTERVIEW 34

BAUPROZESS I BUILDING PROCESS 46

STADTRAUM I URBAN SPACE 56

INTERIEUR I INTERIOR 66

T-CENTER 80 